\title{
Islamic Work Ethics in Building Work Life Balance to Achieve Islamic Job Satisfaction
}

\author{
Eviatiwi Kusumaningtyas Sugiyanto, Taufikur Rahman, Aprih Santoso \\ Semarang University, Semarang, Indonesia \\ IAIN Salatiga, Salatiga, Indonesia \\ Semarang University, Semarang, Indonesia \\ eviatiwisugiyanto@usm.ac.id, takur067782@yaboo.co.id,apribsantoso@usm.ac.id
}

\begin{abstract}
The purpose of this study is to provide an interpretation of library study result on the relationship between Islamic Work Ethics (IWE) in building work life balance (WLB) to achieve job satisfaction in Islam. The method used is library study by tracing related topics. Data comes from primary sources in the form of articles that are relevant to topics. Meanwhile, data analysis used interpretive. The results show that there is an alleged logical relationship between IWE, WLB and job satisfaction in Islam. Application of IWE can build a balance between work and life outside of work. Furthermore, someone who is able to build this balance can feel job satisfaction, in terms of Islamic job satisfaction. The implication of this research, there is an initial assumption of a link between IWE and $W L B$ and job satisfaction in Islam. The future research agenda can test empirically the relationship between these variables by incorporating it into an empirical research model.
\end{abstract}

Keywords: Islamic Work Ethics, Islamic Job Satisfaction, Work Life Balance.

Permalink/DOI: bttps://doi.org/10.18326/infsl3.v14i2. 317-330 


\section{Introduction}

Consumer News and Business Channel (CNBC), in a study stated that 69 percent of HR professionals agree that work life balance $(W L B)$ or the balance of work and daily activities is the main factor affecting the current work experience (Fauzia, 2020). Furthermore, Fauzia (2020) states that jobs that offer $W L B$, according to LinkedIn, are the most influential in the employees' job satisfaction. WLB is defined as a state of balance in which the demands of one's work and personal life are the same (Lockwood, 2003). In a society full of conflicting responsibilities and commitments, WLB has become a major problem in the workplace. The three main factors in the importance of $W L B$ (Lockwood, 2003) are: 1) global competition; 2) new interest in personal life / family values; and 3) workforce that becomes older. The researches show that human resource professionals look for the innovative ways to add to an organization's competitive advantage in the marketplace and to find win-win solution to the WLB challenges.

WLB studies have been widely conducted and focused in the context of western life (J. H. Greenhaus, \& Powell, G. N, 2006; Herman \& Lewis, 2012; Lewis, Gambles, \& Rapoport, 2007). However (Warhurst, 2008) identified three main weaknesses in the $W L B$ debate that have been understood so far. The first one related to the persistent mismatch between supervisors' and employees' goals. The second one related to the difference between "work" and "life". Related to this assumption is "balance", which is the same allocation of time and energy for work and life (Ranjan, 2013). It ignores the perceptual experience of time and is a false dichotomy to assume that the word "balance" means allocating the same amount of energy and time to work-related and non-workrelated tasks (Osoian, 2009; Ranjan, 2013). The third one related to the assumption that work will have negative impact on employees' non-work lives and that the word "life" only revolves around family. To achieve WLB consistently, we must change work ethics and corporate culture through education, acceptance, communication and accountability (Rennar, 2007). WLB is part of work ethics, a worker will accommodate work ethics that includes personal life balance to consider a priority scale, which ones are right and wrong, 
and which are sufficient and excessive (Porter, 2004).

Ethics is an important thing in society including for organizations because it contains values that will encourage a person to work optimally and always be acco m panied by conscience (Bakhri, 2017). Work Ethics in Western society is known as the Protestant Work Ethics (PWE), which forms the backbone of the capitalism ideology. $P W E$ is instrumented to increase the income of Western people, especially the growth of the American economy in the early period (Husin, 2012). Although PWE seems to be able to increase the productivity of the Western economy, and its implementation is focused on Western society, it is the secular elements that are shunned by Moslems to implement (Husin, 2012). In fact, the materialistic nature and the low emphasis on humanistic values have led to an increase in suicide attempts, and led to the birth of an individualistic society (Husin, 2012).

The essence of PWE contains the elements of hard work, hours with little or no free time, pride in work, an orientation towards achievement and wealth gain, and wise investment (Porter, 2004). Murtaza et al. (2014) found that the Protestant Work Ethics has resulted in the concepts of simplicity, individualism, discipline and hard work. PWE is certainly not suitable to be implemented to Moslem workers. Moslem workers have their own values in life. A Moslem's view of life is that work is a form of worship, and is not oriented solely to worldly gain or prosperity. The concept of achieving balance in life and work will differ between the western and the eastern societies, or in Moslem and non-Moslem societies.

Indonesian people, who are predominantly Moslem, tend to apply Islamic values in their work lives. These believed values can influence or direct a person's behavior. Work ethics in Islam is known as the Islamic Work Ethics (IWE). Islamic Work Ethics values are positively work-oriented and balance the individual and the social life (Abu-Saad, 2016). The values in IWE cover all dimensions of life including work in an organization (Ahmad, 2011). Islamic work ethics focuses on different angle as it reflects Moslem traditions and way of life. This will have an impact on how a Moslem has a view on his work life balance and the job satisfaction he gets. Work 
Life Balance in Islamic values cannot be separated from the Islamic Work Ethics, so it is necessary to discuss the relationship between Islamic Work Ethics in Work Life Balance to achieve Islamic Job Satisfaction.

\section{Literature Review}

Work Life Balance (WLB)

The concept of $W L B$ comes from the role theory proposed by Kahn et al in 1964 (Adisa, Abdulraheem, \& Isiaka, 2019), which states that the different roles the individuals play in their lives can conflict with each other (Grzywacz, 2000). As a result, these individuals are faced with challenges in balancing their work roles and personal lives (Feeney \& Stritch, 2017). Working people have the desire to fulfill their commitments to work and family and strive to achieve job satisfaction. The achievement of $W L B$ will have impact on developing maximum career potential and achieving satisfaction and happiness in one's life.

Work life balance is defined as the extent to which a person is bound by the balance between work and family responsibilities ( $\mathrm{J}$. H. Greenhaus, Collins, \& Shaw, 2003). Employees with good WLB show strong commitment to work and life (Virick, Lilly, \& Casper, 2007). WLB is defined as an individual's ability to effectively manage work carried out in career with all other activities that are important to that person's life, such as family development, personal health, community activities, or recreation (Muda et al., 2019). Failure to manage family and career effectively can lead to stress problems at work, role conflicts, mental health and problems, neglect and even divorce (Bodenmann et al., 2016; Jalili, 2017). According to Muda et al. (2019) the advantages of $W L B$ are 1) better physical and mental health, 2) increasing life satisfaction, 3) the effective time management, 4) increasing control over work life, 5) the ability to manage priorities, 6) reducing work stress 


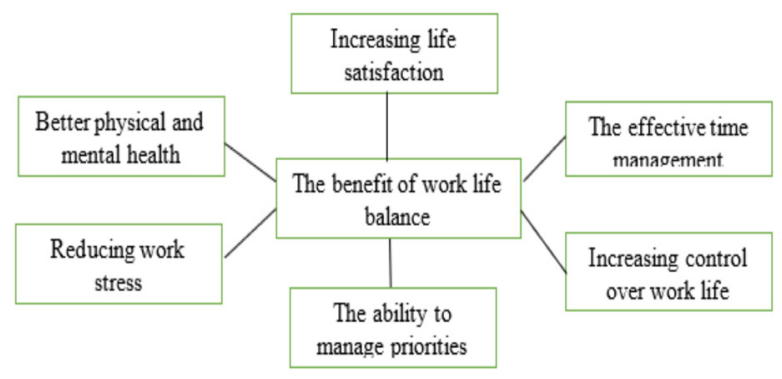

\section{Figure 1. The Benefit of Work Life Balance}

Source: Muda et al., 2019

Many $W L B$ studies have been carried out and focused in the context of western life (J. H. Greenhaus, \& Powell, G. N, 2006; Herman \& Lewis, 2012; Lewis et al., 2007). However, Warhurst (2008) identified three major weaknesses in the $W L B$ debate that have been understood so far. The first one is related to the persistent mismatch between WLB's goals of the superiors and the subordinates. The second one is related to the differences between "work" and "life". Related to this assumption is the "balance" of the same allocation of time and energy for work and life (Ranjan, 2013). It ignores the perceptual experience of time and is a false dichotomy to assume that the word "balance" means allocating the same amount of energy and time to work-related and non-work-related tasks (Osoian, 2009; Ranjan, 2013). The third one is releted to the assumption that work will have negative impact on employees' non-work lives and that the word "life" only revolves around family.

\section{Islamic Work Ethics}

Islamic work ethics is defined as the attitude in work based on religious values, including working optimally, competing fairly, carrying out obligations, providing the best dedication, working together harmoniously without discrimination and earning income according to what is done (Marsudi, Febriani, Sa'diyah, \& Pratika, 2019). According to Ibrahim (2013) the indicators of Islamic Work Ethics consist of 1) religiousity, Islamic values applied in the workplace, 2) effort, perseverance and patience in the workplace, 3) competition, a process of fair competition among employees that 
can improve performance quality. 4) work obligation, responsible and honest attitude in completing work, 5) work process quality, employees' excellence values in applying accuracy and innovative attitude, 6) collectivism, cooperation among employees in the workplace, 7) equality, uniformity in treating other people without distinguishing their status, 8) profit, a condition in which someone gets benefits by giving the best for family or society. From Islamic perspective, ethics is defined as an act that is accepted as a norm that does not conflict with Islamic rules. The work ethics must be universal, so that it can be embraced by any society regardless of religion, color, race or ethnicity. The important values in $I W E$ are shown in the table below (Ibrahim, 2013):

\section{Table 1. The Values of Islamic Work Ethics}

\begin{tabular}{lll}
\hline No & \multicolumn{1}{c}{ Values } & \multicolumn{1}{c}{ Quran References } \\
\hline 1 & Truthfulness & QS. Al-Maidah 5: 119 \\
2 & Honesty & QS. Al-Baqarah 2: 261-283 \\
3 & Consultation & QS. Al-Shura 42: 38; Ali 'Imran 3:159 \\
4 & Keeping promise & QS. Al-Saff 61:2-3 \\
& Fairness and & QS. Al-Nahl 16: 90; Hud 11: 85; Al-Isra' 17: \\
& Justice & 35; Al-Rahman 55: 8-9; Al-Baqarah 2:282 \\
& & QS. Al-Nahl, 16:90; Al-Baqarah 2: 283; Al- \\
& Trustworthiness & Nisa 4:58 \\
& & QS. Al-Furqan 25:63; Ali 'Imran 3:134; \\
7 & Patience & Al-Baqarah 2:153; Al-Muzammil 73:10; Al- \\
& & Maarij 70:5 \\
8 & Humbleness & QS. Al-Shu'ara 26: 215; Hud 11:23 \\
& & QS. Al-Ahzab 33:35; Al-Hadid 57:18; Al- \\
& Generosity & Baqarah 2:272 \\
& & QS. Al-Furqan 25:72; Al-Baqarah 2:188; Al- \\
10 & Dignity & Tawbah 9:34 \\
& & QS. Al-Hujurat 49:10, 13 \\
11 & Friendliness & QS. Al-Qashas 28:26 \\
12 & Professionalism & QS. Al-Maidah 5:8 \\
13 & Punctuality &
\end{tabular}




\begin{tabular}{clc}
\hline No & \multicolumn{1}{c}{ Values } & \multicolumn{1}{c}{ Quran References } \\
\hline \multirow{2}{*}{14} & $\begin{array}{l}\text { Cooperation and } \\
\text { Collaboration }\end{array}$ & QS. Al-Maidah 5:2 \\
15 & Self-Reliance & QS. Al-Najm 53:39 \\
16 & Transparency & QS. Al-Baqarah 2:282 \\
\hline \multicolumn{3}{c}{$I W E$ is the implementation of duties in fulfilling religious }
\end{tabular}
obligations as part of worship which implementation is based on the Qur'an and Sunnah (Ibrahim, 2013). Overall, IWE principles focus on the relationship between human and human, human and their environment, and human and their creators (Ibrahim, 2013). So it can be concluded that the principles of Islamic ethics are depended on one's religious beliefs in Allah SWT. An organization can directly gets benefit from having devout workers because they are balanced in all aspects and according to the philosophical view, a devout devotee will not only increase the performance and productivity of a company, but will also result in noble behavior among the workers (Ibrahim, 2013). Therefore, all efforts to improve organizational performance must be carried out by instilling Islamic priorities based on faith and devotion to Allah (Husin, 2012).

\section{Islamic Job Satisfaction}

In Islam, work is considered as the fact of life and the mystery of creation (Khanifar, 2011). People express their existence with effort and determine their true value by working. In Islam, work and effort are like Jihad in God's way. Prophet Muhammad SAW stated that "A person who strives for family, is like a soldier who performs jihad in Allah's way". In Islamic perspective, job satisfaction is the serenity obtained by employees before, during and after doing the work, based on the belief that work is worship done to achieve God's pleasure (Saadiah, 2014). There are four indicators of Islamic job satisfaction based on the elements of human creation according to the Qur'an with reference to the interpretation of al-Ghazali (Marsudi et al., 2019). First, rubiyyah job satisfaction which refers to the satisfaction provided by the intrinsic satisfaction of a Moslem if the work is done to achieve God's pleasure and to be closer (taqarrub) to God. Second, this is called intellectual job satisfaction (Aqliyyah) which refers to the happiness because the employees 
acquire new knowledge within themselves. The third is social work satisfaction (nafsiyyah). It refers to the pleasure the employees have when they get to know each other. The last one is material job satisfaction (jasadiyyah). This is the happiness the employees feel when they get their payroll on time. Someone's satisfaction will be felt if they get what they are trying for (work goals) (Khanifar, 2011).

\section{Methods}

This study used qualitative method to provide an interpretation of the relationship between Islamic Work Ethics (IWE) in building Work life balance (WLB) in order to achieve job satisfaction in Islam. The data source of this research comes from primary sources, namely documents that are relevant to the research topic. The research topic was divided into three, namely Islamic Work Ethic (IWE), Work life balance (WLB) and job satisfaction in Islam. Data collection techniques include editing, organizing and finding. Meanwhile, data analysis used interpretation to explain the relationship between the three research topics.

\section{Results and Discussion}

The Relationship of Islamic Work Ethics in Work Life Balance to achieve Islamic Job Satisfaction

Islamic Work Ethics (IWE) contains universal Islamic values, so that it is in accordance with human needs in the world and as the preparation for the life in the hereafter. Such value system cannot be aligned with the norm or application of society which tends to be situational and change depends on the standards and the acceptance of society. These believed values can influence or direct a person's behavior. Islamic behavior covers all aspects of human life and produces a balanced personality by simultaneously meeting their spiritual and material needs (Akhtar, 1996). There is a concept known as 'al-tawazun' in Islam which denotes the concept of balance and equilibrium (Muda et al., 2019). Allah has revealed to all His creatures to live in balance just as He has created nature and its existence in balance. In Islam, the concept of balance and equilibrium is known as al-tawazun, and in many ways, it is called moderation (al-wasatiyyah). In discussing these concepts, there are writers who distinguish the two concepts while there are also those who define them under the same meaning. 
The concepts of al-tawazun and al-wasatiyyah are similar according to al-Qaradawi, because these two concepts of balance provide fair meaning between two opposing sides without affecting the other (Muda et al., 2019). While others who distinguish the two, al-wasatiyyah comes from the word 'wasat' in Arabic which means a middle way approach (Muda et al., 2019). Moslems are described by Allah as human beings who can become the witness to all human actions. Therefore all Islamic teachings and its system are enforced in an integrated and balanced manner, on the basis of which each part is interrelated (Muda et al., 2019).

The relation between Islamic Work Ethics (IWE) and Work Life Balance (WLB) is explicitly explained by Ali and Al-Owaihan (2008), that the construction of IWE captures the essence of the work ethics in Islam regarding the need to build a balance in one's personal and social life. Generally, IWE is built on four main concepts: effort, competition, transparency and morally responsible behavior (Ali \& Al-Owaihan, 2008). The simultaneous presence of these four concepts ensures balanced benefits for individuals and society. Thus it is important that one must be able to organize his daily activities effectively and flexibly. The concept of WLB in Islam must also include observations of both physical and psychological health. This is in line with the need to preserve and protect the five objectives of Islamic Law, namely; protection of religion, intelligence, self, descent, and property (Muda et al., 2019). Therefore, any action or behavior which undermines any of the five goals of Islam is prohibited in Islam. The emphasis on these five fundamentals should be the goal in implementing a balanced work life. The real essence of maintaining balance in one's life according to Islamic principles is derived from whether it is religion, worship, relationship, idea, or daily activities (Muda et al., 2019). Practicing work-life balance will also demand effective time management. Work value from an Islamic perspective systematically considers all aspects, not only moral and spiritual aspects of work values, but also material aspects, work environment happiness and job satisfaction (Khanifar, 2011).

The main goal of a Moslem is to seek the pleasure of Allah. Sharia provides guidance and incentives to live such a life. The goal of 'pleasing Allah' deeply affects a person's psychology and 
mentality and makes them spiritually strong. With that power, they focus on their goals by resisting worldly temptations. To achieve a balance of life, the life of a Moslem rests on three basic principles: tawhid, khilafah and al-Akhira (Akhtar, 1996). This ethics component in Islam is integrated into the daily life of a Moslem. It is said that in a climate of Islamic economic philosophical views, it is ethics that dominate the economy and not the other way around, and that Islamic economics is characterized as ethics (akhlaqi) besides being pious (rabbani), humane (human) and balanced (wasati) (Ibrahim, 2013).

Work ethics is indicated to have the greatest impact on job satisfaction (Rafiki \& Wahab, 2014). According to Parboteeah, Paik, and Cullen (2009), a Moslem tends to pursue the extrinsic and intrinsic aspects of work for their job satisfaction. The extrinsic aspect means that the work is an economic resource for survival, and is well used for the afterlife objectives. Meanwhile, the intrinsic aspect includes having an interesting job or a job that is useful to the society, etc. in the positive way, as well as' work is considered as the source of independence and a means of fostering personal growth, self-respect, contentment and self-fulfillment (Yousef, 2001). Spirituality helps a person prioritize the needs of their family and their life (Grine, 2015).

A Moslem needs a balance between their work and family, on the grounds that they are required to be good not only in their work and towards the people around them, but also for their parents and family (Grine, 2015). Taking care of the family is the top priority for a Moslem. IWE will lead to $W L B$ based on Islamic values which will directly create Islamic job saticfaction. Yousef (2001) explains that $I W E$ is very supportive in creating job satisfaction. Furthermore, the employees who are able to balance their work and their personal lives are able to increase their job satisfaction (Hasan \& Teng, 2017). With $W L B$ obtained through the implementation of Islamic ethics values, one can achieve Islamic job satisfaction, namely taqarrub, aqliyyah, nafsiyyah and jasadiyyah. They will find peace before, during and after conducting work, based on the belief that work is worship done to achieve God's pleasure (Saadiah, 2014). 


\section{Conclusion}

Islam provides detailed regulations on human life and at the same time maintains its spiritual perspective. Therefore, working in Islam lies on the core of faith and is considered as the integral part of life. The differences of work ethics in Islam and other religions are the actions and the intentions. These differences are the significant pillar of $I W E$. Islam places more emphasis on intentions than results and emphasizes the social aspects in the workplace, as well as their impact on society (Ali \& Al-Owaihan, 2008). Islam implies that work is a virtue in meeting one's needs, and is a necessity to establish a balance in one's individual and social life. Work is evaluated in terms of benefits to society. Every activity deemed harmful, even if it generates significant wealth for those who do it, is considered illegal. Working in Islam has the aspects of economic, moral, psychologic and social (relational) (Ali \& Al-Owaihan, 2008). Work must be useful and meaningful. That is, it must be useful for others and society as the source of pride and the dignified and balanced life. Thus, with the application of IWE someone can build a balance between work and life outside of work (work life balance). Furthermore, someone who is able to build $W L B$ will be able to feel job satisfaction, in this case job satisfaction in Islamic way.

\section{References}

Abu-Saad, I. (2016). Individualism and Islamic Work Beliefs. Journal of Cross-Cultural Psychology, 29(2), 377-383. doi:10.1177/0022022198292007

Adisa, T. A., Abdulraheem, I., \& Isiaka, S. B. (2019). Patriarchal hegemony. Gender in Management: An International Journal, 34(1), 19-33. doi:10.1108/gm-07-2018-0095

Ahmad, M. S. (2011). Work ethics: an Islamic prospective. Journal of Human Sciences, 8(1), 850-859.

Akhtar, M. R. (1996). Towards an Islamic Approach for Environmental Balance. Islamic Economic Studies, 3(2), 1-20.

Ali, A. J., \& Al-Owaihan, A. (2008). Islamic work ethic: a critical review. Cross Cultural Management: An International Journal, 15(1), 5-19. doi:10.1108/13527600810848791 
Bakhri, S., Ardi, R. P., Masud, F., \& Suharnomo, M. (2017). Exploring the Role of Islamic Work Ethics for Organizations in Indonesia. Paper presented at the In Mulawarman International Conference on Economics and Business (MICEB 2017).

Bodenmann, G., Charvoz, L., Bradbury, T. N., Bertoni, A., Iafrate, R., Giuliani, C., . . . Behling, J. (2016). The role of stress in divorce: A three-nation retrospective study. Journal of Social and Personal Relationships, 24(5), 707-728. doi:10.1177/0265407507081456

Fauzia, M. (Producer). (2020, 6/25/2020). LinkedIn: Work Life Balance Kunci Kepuasan Bekerja. Retrieved from https://money.kompas. $\mathrm{com} / \mathrm{read} / 2020 / 01 / 23 / 121200826 /$ linkedin--work-life-balancekunci-kepuasan-bekerja

Feeney, M. K., \& Stritch, J. M. (2017). Family-Friendly Policies, Gender, and Work-Life Balance in the Public Sector. Review of Public Personnel Administration, 39(3), 422-448. doi:10.1177/0734371x17733789

Greenhaus, J. H., \& Powell, G. N. (2006). When work and family are allies: A theory of work-family enrichment. Academy of Management Review, 31(1), 72-92.

Greenhaus, J. H., Collins, K. M., \& Shaw, J. D. (2003). The relation between work-family balance and quality of life. Journal of Vocational Behavior, 63(3), 510-531. doi:10.1016/s0001-8791(02)00042-8

Grine, F., Fares, D., \& Meguellati, A. (2015). Islamic spirituality and entrepreneurship: A case study of women entrepreneurs in Malaysia. The Journal of Happiness \& Well-Being, 3(1), 41-56.

Grzywacz, J. G., \& Marks, N. F. (2000). Reconceptualizing the workfamily interface: An ecological perspective on the correlates of positive and negative spillover between work and family. . Journal of occupational health psychology, 5(1), 111.

Hasan, N. A. B. B., \& Teng, L. S. (2017). Work-Life Balance and Job Satisfaction among Working Adults in Malaysia: The Role of Gender and Race as Moderators. Journal of Economics, Business and Management, 5(1), 18-24. doi:10.18178/joebm.2017.5.1.478

Herman, C., \& Lewis, S. (2012). Entitled to a Sustainable Career? Motherhood in Science, Engineering, and Technology. Journal of Social Issues, 68(4), 767-789. doi:10.1111/j.1540-4560.2012.01775.x 
Husin, W. N. W., \& Norhasniah, W. . (2012). Work ethics from the Islamic perspective in Malaysia. European Journal of Social Sciences, 29(1), 51-60.

Ibrahim, A., \& Kamri, N. A. (2013). Measuring the Islamic Work Ethics: An Alternative Approach. Islamic Perspective on Management: Contemporary Issue, Kuala Lumpur: YaPEIM Management Academy (135-16).

Jalili, L., Najar, S., Nezamivand-Chegini, S., \& Yaralizadeh, M. (2017). The relationship between factors related to divorce request and mental health among divorce applicant women referred to legal medicine organization in Ahvaz, Iran. Journal of family $\varepsilon$ reproductive bealth, 11(3), 128.

Khanifar, H., Matin, H. Z., Jandaghi, G., Gholipour, A., \& Hassanzadeh, M. S. (2011). Identifying the dimensions and components of Islamic work values (IWV) for public services sector of Iran. European Journal of Social Sciences, 22(2), 246-261.

Lewis, S., Gambles, R., \& Rapoport, R. (2007). The constraints of a 'work-life balance' approach: an international perspective. The International Journal of Human Resource Management, 18(3), 360-373. doi:10.1080/09585190601165577

Lockwood, N. R. (2003) Work/life balance. Challenges and Solutions. In: SHRM Research, USA.

Marsudi, Febriani, R., Sa'diyah, C., \& Pratika, Y. (2019). The Implementation of Islamic Values in Improving the Quality of Employee Performance in Workplace. KnE Social Sciences, 3(13). doi:10.18502/kss.v3i13.4231

Muda, T. F. M. T., Husin, S. N. M. S., Ismail, S. K., Yusoff, Z. M., Salleh, S. F., Zakaria, N. N. b., \& Chik, W. M. Y. W. (2019). Working Women and the Islamic Work-Life Balance Concept. International Journal of Academic Research in Business and Social Sciences, 9(11). doi:10.6007/IJARBSS/v9-i11/6603

Murtaza, G., Abbas, M., Raja, U., Roques, O., Khalid, A., \& Mushtaq, R. (2014). Impact of Islamic Work Ethics on Organizational Citizenship Behaviors and Knowledge-Sharing Behaviors. Journal of Business Ethics, 133(2), 325-333. doi:10.1007/s10551-014-2396-0 
Osoian, C., Lazar, L., \& Ratiu, P. (2009). The benefits of implementing and supporting work-life balance policies in organizations. . Paper presented at the Managerial Challenges of the Contemporary Society.

Parboteeah, K. P., Paik, Y., \& Cullen, J. B. (2009). Religious Groups and Work Values. International Journal of Cross Cultural Management, (1), 51-67. doi:10.1177/1470595808096674

Porter, G. (2004). Work, work ethic, work excess. Journal of Organizational Change Management, 17(5), 424-439. doi:10.1108/09534810410554461

Rafiki, A., \& Wahab, K. A. (2014). Islamic Values and Principles in the Organization: A Review of Literature. Asian Social Science, 10(9). doi:10.5539/ass.v10n9p1

Ranjan, R., \& Prasad, T. . (2013). Literature Review Report on-"WorkLife Balance of Loco-Pilots (Railway Drivers) in India". . European Journal of business and management, 5(19), 17-27.

Rennar, H. (2007). In search of true work/life balance: in order to consistently attain work/life balance, we must change our work ethic and corporate culture through education, acceptance, communication and accountability. Financial Executive, 23(3), 57.

Saadiah, H., Mohammad, B., \& Hayati, S. . (2014). The Role Integrity As Mediator Between Work Satisfaction And Work Performance In The Perspective Of Islam: An Empirical Approach Using SEM/AMOS Model. Impact: International Journal of Research in Applied, Natural and Social Sciences, 2(1).

Virick, M., Lilly, J. D., \& Casper, W. J. (2007). Doing more with less. Career Development International, 12(5), 463-480. doi:10.1108/13620430710773772

Warhurst, C., Eikhof, D. and Haunschild, A. . (2008). Out of balance or just out of bounds? Analysing the relationship between work and life. Retrieved from PalgraveMacmillan, Basingstoke.:

Yousef, D. A. (2001). Islamic Work Ethic - A Moderator between Organizational Commitment and Job Satisfaction in a Crosscultural Context. Personnel Review, 30, 152-164. 